\title{
Hinn and hinn: Early Icelandic as the clue to the history and etymology of two Old Scandinavian words
}

\author{
Ulla Stroh-Wollin (10) \\ Department of Scandinavian Languages, Box 527, SE-751 20 Uppsala, Sweden \\ Email for correspondence: ulla.stroh-wollin@nordiska.uu.se
}

(Received 26 August 2019; revised 02 February 2020; accepted 12 May 2020; first published online 13 October 2020)

\begin{abstract}
The history and etymology of Old Scandinavian hinn is a disputed matter. One question concerns whether hinn as a contrastive demonstrative indicating 'the other (one)/the former (one)' and hinn as a pre-adjectival article, both of which to some extent are still found in present-day Icelandic, are related or not. Another issue concerns the fact that hinn has no immediate parallel in Germanic outside Scandinavia, which has led scholars to assume that it is a ProtoScandinavian innovation. This paper argues that Old Scandinavian possessed two hinn words with separate backgrounds, one stemming directly from an anciently inherited distal demonstrative, and one from an innovated proximal demonstrative. However, the innovation was no more founded on common Germanic material than the former hinn was. Instead, it arose from the reinforcement of an ancient precursor. This precursor is traceable in early Icelandic enn, which was used as a pre-adjectival article and as a primitive post-nominal definiteness marker.
\end{abstract}

KEYWORDS etymology; hinn; Old Icelandic; Old Scandinavian; Old Scandinavian pre-adjectival articles; Scandinavian definite suffix

\section{Introduction}

Modern Icelandic dictionaries have separate entries for the demonstrative hinn 'the other (one)/the former (one)' and the pre-adjectival definite article hinn. This arrangement is well-warranted considering the inflectional differences, even though these are restricted to the neuter, nominative and accusative singular forms, which are hitt and hið, respectively; see (1). ${ }^{1}$

$\begin{array}{rlll}\text { (1) a. Petta hús er gult, hitt } & \text { er hvítt. } \\ \text { this house } & \text { is yellow, the.other.one is white } \\ \text { b. Hid ljósa man } & \text { (title of book by Halldór Laxness) } \\ \text { the light maiden } & & \end{array}$

The demonstrative is also distinguished from the article in that a following noun has to appear in the definite form; compare hitt húsið - ${ }^{\star}$ hitt hús 'the other house'. The

(C) The Author(s) 2020. This is an Open Access article, distributed under the terms of the Creative Commons Attribution licence (http://creativecommons.org/licenses/by/4.0/), which permits unrestricted re-use, distribution, and reproduction in any medium, provided the original work is properly cited. 
article + adjective always precedes nouns without the definite suffix ${ }^{2}$; compare hið ljósa man - *hið ljósa manið. However, these grammatical rules were not settled in Old Icelandic (see Pfaff 2019), whereas an orthographic distinction is manifest as far back as the records go. The neuter form of the demonstrative is normally spelled $<\mathrm{tt}>$ or $<\mathrm{T}>$ in early manuscripts, in all probability reflecting a long $t$-phoneme, then as well as now, while the neuter form hið of the article goes back to hit, with a short $t$-phoneme, normally written $<\mathrm{t}>$ in Old Icelandic manuscripts.

The phonological distinction, clearly manifested in the spelling, suggests that we are dealing with two different words also in Old Icelandic. Nevertheless, it has been argued that the definite article has arisen from the demonstrative. This is of course reasonable considering that most forms of the paradigms are identical and that definite articles generally have their origin in demonstratives. However, the assumption of a common source is also challenged by the fact that the demonstrative forms always show the initial $h$ right from the beginning, whereas the first instances of an article-like word in the mediaeval Icelandic manuscripts are normally $h$-less forms, such as enn and inn, which rather points to a different origin.

The situation on the mainland, on the other hand, confuses the picture, as the pre-adjectival word only occasionally lacks the $h$ in these varieties. The Mainland Scandinavian languages have all ended up with den $(<$ penn $\leftarrow s \bar{a})$ as their preadjectival definite article, but hinn is found before weakly inflected adjectives in the Viking Age runic inscriptions (mostly in post-nominal appositive phrases) and in early mediaeval, mainly Norwegian, manuscripts (in pre-nominal attributes). The first known instance is the appositive phrase hinn purmo $i$ ' the bold' on the Rök stone (Ög 136) from the 9th century.

So, the relation between hinn and enn/inn, as well as between the different uses of hinn, is a disputed matter. The difference in form as regards the demonstrative hinn and the pre-adjectival enn/inn in early Icelandic points towards separate origins, which is also the view of some scholars. The early instances of pre-adjectival hinn on the mainland have led others, in contrast, to believe in a common origin, with the $h$-less variants ensuing from $h$-drop in unstressed positions. The former assumption raises the question of why the $h$-forms seem predominant already very early on the mainland. The latter assumption, on the other hand, suffers from the drawback that it is unclear why the pre-adjectival article is represented almost exclusively by $h$-less forms in the earliest Icelandic manuscripts, and almost only by $h$-forms in runic inscriptions and manuscripts from the mainland. Should we not expect a more varied distribution?

Driscoll (2017:17ff.) gives an informative overview of what he calls the onesource and two-source theories, from Torp (1919) and Jónsson (1921), who take the former position, and Pokorny (1959), who supports the latter. After the first decades of the 20th century, the topic has not attracted much attention outside the circle of etymologists. However, Martin Syrett argues that 'it is unlikely that both [hinn and inn] could be distinct inherited forms' (Syrett 2002:723). When the relation between hinn and the $h$-less forms is at all addressed in later contributions, it seems as if a single source is taken for granted, so e.g. in Pfaff (2019). Skrzypek (2009) also assumes only one source, but turns the relation upside-down, i.e. takes hinn as secondary to inn. It is also noteworthy that later scholars normally represent the $h$-less 
forms with inn exclusively, and pay no regard to the enn variant. I believe this is a mistake.

In the following, I will argue for a two-source solution, suggesting that the definite article hinn is not a descendant of the demonstrative hinn 'the other/the former', from Proto-Scandinavian *hinar, but has developed from a separate demonstrative, a Proto-Scandinavian ${ }^{\star} e n a R$, later visible in the early Icelandic enn. The corresponding hinn on the mainland is, according to the proposal, due to an early Proto-Scandinavian reinforcement of ${ }^{\star} e n a R$, an innovation that was not spread over the entire Scandinavian-speaking area, which explains why the colonizers of Iceland brought with them enn, actually not only as a pre-adjectival article but also as a primitive post-nominal definiteness marker, the nascent definite suffix. The quality of the vowel of the post-nominal marker, as we will see, was soon adjusted in accordance with other endings when cliticizing to the noun (enn $\rightarrow$ -inn), whereas the pre-adjectival word successively changed from enn to inn and later from inn to hinn.

This proposal obviously has merit; so why has the picture remained so unclear for so long? One confusing circumstance is of course the formal merger of the two words in Mainland Scandinavian - if we accept a two-source theory. However, even if we initially find a merger of this kind unlikely, it is reasonable to consider it as a possibility, given the division of labour between hinn and the $h$-less variants in early Icelandic. This is the main theme of Section 3 below, which follows directly after some comments on methodological conventions in Section 2, especially the terminology, principles for citation, etc. Section 3 also contains some reflection on the significance of the deixis and the referential nature of the demonstratives.

The question of why there are two $h$-less variants of the pre-adjectival article in early Icelandic is almost never addressed. Generally, enn and inn are regarded as just two variants in free variation. Admittedly, this assumption is supported by the prevalent use of $<\mathrm{e}>$ for short unstressed /i/ in the very early Icelandic manuscripts, as shown by Hreinn Benediktsson (Benediktsson 2002 [1962]). Nevertheless, I find it crucial to attach great importance to the distribution of enn forms and inn forms in early Icelandic, and this is the theme of Section 4.

In Section 5, I discuss the history and etymology of the Old Scandinavian contrastive demonstrative hinn and pre-adjectival enn and hinn in the light of what emerges from the preceding sections. Finally, Section 6 adds a comment on how our conception of the prehistory of the Germanic languages may affect how we draw conclusions on the etymology of certain words.

\section{Terminology, citation, etc.}

\subsection{Time periods and Scandinavian varieties}

Scandinavian linguists use different conventions when it comes to the division and naming of time periods in the histories of their respective languages. The formally parallel terms Old Icelandic, Old Norwegian, Old Danish and Old Swedish actually encompass somewhat different periods of time. In the following, when there is no need to be more precise, I use these designations as labels for the different varieties as found in mediaeval manuscripts. The modifier Old may also be used before 
Scandinavian to cover 'mediaeval'. (As we unfortunately have practically no written evidence of Faroese from the Middle Ages, I make no reference to this variety in the following.)

Sometimes, the modifier early is used (instead of Old) in connection to any geographical variety. This is to accentuate the fact that the phenomenon under discussion was part of the language during an early period of the Middle Ages, and possibly even during the preceding Viking Age, but not (necessarily) during the late Middle Ages. The term Proto-Scandinavian refers to the Scandinavian branch of Germanic before $c .800$. Traditionally, the label is taken to cover the first eight centuries $\mathrm{AD}$, but in this context, I see no reason to assume a specific lower limit (see further, Section 6).

Most often, varieties will be named as Icelandic, Norwegian, Danish and Swedish. Occasionally, the traditional division between West Norse, covering the Icelandic and Norwegian varieties, and East Norse, covering the Swedish and Danish varieties, is applicable. Interestingly, however, the story of enn reveals an isogloss that probably ran through Norway before the colonization of Iceland, and later between Iceland and the Scandinavian Peninsula. Thus, it will often be convenient to contrast Icelandic with Mainland Scandinavian, the latter including Danish and Swedish as well as Norwegian.

\subsection{Representation of forms}

In early Scandinavian, as of course Proto-Scandinavian, nominal words were inflected for gender, number and case. Following tradition, I use the masculine singular nominative forms as representatives for paradigms. As far as possible, I will use early Scandinavian forms such as hinn and enn. However, I try to avoid these forms when talking about Proto-Scandinavian, as we must assume that the primary Proto-Scandinavian equivalents were ${ }^{\star}$ hinaR and ${ }^{\star}$ enaR with the older masculine singular nominative ending $-R$ on the stems ${ }^{*}$ hina- and ${ }^{*} e n a-{ }^{3}$ However, the unstressed vowel of the stems was syncopated early on, and to avoid complicating things more than necessary, I take the hin- and en-stems to be representative of Proto-Scandinavian as well.

After syncope of the vowel, the ending for the masculine singular nominative, $-R$, was adjacent to stems with final $n$, which led to an assimilation of the $n$ and the $R$, resulting in a long $n:{ }^{\star}$ hinaR $>{ }^{\star}$ hinR $>$ hinn. Similar assimilations also occurred in the genitive and dative forms of the feminine singular (> hinnar and hinni, respectively) and in the (common) genitive form of all genders in the plural (> hinna). In the nominative and accusative singular neuter, the $n$ of the stem and the ending $t$ normally ended up as a long or, for some reason (see Section 5.2 below), a short $t$, $/ \mathrm{nt} />/ \mathrm{t}(:) /$, giving us forms such as hitt and et. Occasionally, however, we also meet the unassimilated neuter form hint in Old Danish (Lund 1877) and Old Swedish (Schlyter 1877, Söderwall 1884-1918).

The most frequent demonstrative in Scandinavian will be represented as sä/penn below. The double label is based on the actual usage. The paradigm originally had suppletive singular nominative forms for the masculine and feminine genders, $s \bar{a}$ and $s \bar{u}$, respectively, while the initial consonant of other forms of the paradigm was a voiceless dental fricative (as in the only preserved, neuter, form in English, 
that). Not very surprisingly, the suppletive forms were successively exchanged for more regular ones, penn and $p \bar{e}$, in the mainland varieties, early on in East Norse and a bit later in Norwegian. (The modern languages have den for the common gender and det for the neuter.) Icelandic, on the other hand, still adheres to the old forms. The reinforced variant of sä/penn (corresponding to English this) turns up in several guises, e.g. sjá, pessi or penni.

The macron in $s \bar{a}$ signifies that the vowel is long, and is henceforth used when the topic is common Scandinavian. ${ }^{4}$ When referring to West Norse exclusively, however, long vowels will be marked with an accent, as in e.g. sjá, in accordance with the traditional normalization of West Norse. Long consonants are represented by geminates, as e.g. in hinn and enn.

\subsection{Grammatical terminology}

The modern Scandinavian languages have mandatory definiteness marking. All (standard) varieties of Scandinavian make use of a definite suffix on the noun as the only way to mark definiteness as long as no modifier precedes the noun. This suffix is here taken to emanate from enn in Icelandic, as hinted at above, and from the corresponding hinn on the mainland. As further developed in Section 3.1, it is not clear from the earliest Icelandic manuscripts how far the process towards complete suffixation had proceeded before the 13th century, but it seems as if non-cliticized enn forms were also generally void of all deictic meaning, which hopefully justifies the label POST-NOMINAL DEFINITENESS MARKER used here.

Apart from the definite inflection of nouns, the modern Scandinavian languages possess pre-posed definite articles to be used in front of adjectival attributes and other pre-nominal modifiers: den in Mainland Scandinavian, tann in Faroese and hinn in Icelandic (but refer to note 1). However, while these words in the modern varieties are true definite articles, this is not the case for pre-adjectival hinn or enn/inn in early Scandinavian, even though they certainly evoked a definite understanding of the phrase. The appearance of pre-adjectival hinn and enn/inn is not related to the development of definiteness marking. Instead they seem to have been more or less obligatory companions to so-called weakly inflected adjectives as far back as we can see (i.e. in Viking Age runic inscriptions from the 9th century onward). ${ }^{5}$ Thus, formally, hinn and enn/inn headed adjectival phrases in early Scandinavian, not noun phrases, i.e. in the sense of determiners (see Pfaff 2019:24ff.). The formal function of these pre-adjectival words is still unclear, but for the sake of simplicity I will label them PRE-ADJECTIVAL ARTICLES - and avoid the attribute definite.

\subsection{Citation and glosses}

When citing from manuscripts, I follow diplomatic editions, but practise some normalizing of the orthographically complicated West Norse examples. Of course, nothing of relevance to the subject under discussion will be suppressed. It is important to be aware that, nowadays, mediaeval West Norse manuscripts are often cited from normalized editions, where instances of enn are reproduced as inn. Even 
normalized editions where hinn represents inn as well as enn are found. In the following, all forms of hinn, inn and enn appear exactly as written in the manuscripts.

When citing runic inscriptions, I will in most cases use the transcriptions, i.e. interpretations of the words written in the Latin alphabet and in accordance with modern orthographic norms. Occasionally, I will also give transliterations of rune sequences. Transliterated runes are given in bold face. The sigla presented in connection to runic inscriptions refer to their designations in the national editions of runic inscriptions and the electronic Scandinavian Runic Text Database. (The list of references includes the latter source.)

For the sake of simplicity, I will not provide a grammatical definition of forms when glossing examples, with the exception of verbs in the present subjunctive, for which there are no direct equivalents in English. Instances of hinn, inn and enn are rendered in the glossed sequence exactly in the form they appear in the original, but in capitals. The same principle also applies to some instances of sâ/penn that are not used in the sense of 'this' or 'that'.

\section{Hinn vs. enn/inn}

This section aims at pinpointing the syntactic and other characteristics of hinn and enn/inn in early Icelandic in comparison with the situation in the contemporary mainland varieties, because the very clear division of labour between hinn and the $h$-less variants in early Icelandic may be the clue to a better understanding of why we find forms of hinn in very disparate uses on the mainland. Section 3.1 is devoted to an account of the syntactic uses of hinn and enn/inn, Section 3.2 comments on the spelling of the neuter singular forms of the nominative and accusative cases, and Section 3.3 discusses the deictic and referential nature of the respective words in relevant uses. The most important aspects are summarized in Section 3.4.

\subsection{Syntactic functions}

The below account of the syntactic uses of hinn and enn/inn in early Scandinavian starts with an overview of the situation in the early mainland varieties. All relevant syntactic functions were here fulfilled with hinn forms, which gives us a convenient point of departure for the following comparison with the usage in Iceland.

\subsubsection{Early Mainland Scandinavian}

Historical dictionaries and handbooks of older date dealing with varieties of Old Mainland Scandinavian often treat hinn as one word, irrespective of syntactic function. A very clear account of the different uses is found in the glossary to the editions of the Old Norwegian laws by Storm \& Hertzberg (1895:286-287). Storm \& Hertzberg identify five distinct functions of hinn:

1. as a demonstrative contrasting 'the other' or 'the former' to someone or something mentioned earlier;

2. in connection to a following relative clause;

3. as an attributive demonstrative; 
4. as a definite article before adjectives;

5. as a suffixed definite article on nouns.

Below, I will first comment upon and exemplify these uses of hinn in turn, before comparing them with their Icelandic counterparts (in Section 3.1.2).

The first function, the contrastive demonstrative, is in fact already demonstrated in (1a), and is fairly well attested in both West Norse and East Norse, not least in the mediaeval provincial laws. The example in (2) gives an example from the (older) law of the Swedish province Västergötland (Äldre Västgötalagen, early 13th century; ed. Wiktorsson 2011:128-129).

(2) Takar mapær bundin piuf mæp rani. af manni. han skal skirskutæ takes man bound thief with robbery from man he shall proclaim firi næstu manni ok i næstæ by. at han ær piufs sins ræntær before nearest man and in nearest village that he is thief his robbed ok py ær hin sakær at. xl Markær. and thus is HIN guilty to 40 mark

'If a man robs another man of a bound thief, [then] he [= the robbed man] shall proclaim to the nearest man and in the nearest village that he has been robbed of his thief and with that, the former [ = the robber] is fined 40 mark.'

The second function, i.e. hinn as antecedent to a relative clause, is sometimes disregarded in accounts of Old Scandinavian, probably because it is not distinguished from the contrastive demonstrative. Admittedly, hinn + relative is sometimes used when there are two contrasting referents. However, this is not necessarily the case, as seen in (3), also from the Västergötland law (ed. Wiktorsson 2011:94). What referent the noun phrase corresponds to is made clear in these cases by the content of the relative clause (underlined in the example).

(3) Flögher fæ i gærpi sva at ængin æltir far banæ af liggi runs animal in fence so that no.one drives gets death of lie:SG.PRS.SBJV vgilt. Æn flögher or gærpi gialdi hin aptær. gærp. a. without.fine but runs out.of fence pay:SG.PRS.SBJV HIN after $\overline{\text { fence owns }}$ 'If an animal runs into a fence without anyone driving it [and] dies thereof, no fine shall be imposed. But if it runs through the fence, [then] the one who owns the fence shall reimburse [the owner of the animal].'

It should be added that hinn antecedents of this kind could precede restrictive 'that'-clauses in addition to relative clauses. Furthermore, the same types of subclauses also already had forms of sä/penn as antecedents in Old Mainland Scandinavian. Today, den $(<$ penn $)$ is the only alternative.

The third function, as an attributive demonstrative, is rarely attested. Storm \& Hertzberg (1895:287) present only one example, the one in (4), from the old law of Gulaping in Norway (Den ældre Gulathings-Lov, manuscript from the early 13th century, possibly reflecting earlier versions; here cited with some more context from the edition of Eithun, Rindal \& Ulset 1994:76). The 'indebted woman' in (4) is to be understood as someone who is doing work to pay off a debt. Normally, a fine would 
have been imposed if she was hurt by someone (on par with the fine for a woman out of debt), but apparently this right does not apply if she has a relationship with a thrall.

(4) En ef skulldar kona legst með træle. pa a armaðr ekkí a henne but if indebted.woman lies with thrall then owns bailiff not on her fyrr en hon have golldet hína skulld. before she have:SG.PRS.SBJV paid HINA debt

'But if an indebted woman sleeps with a thrall, then the bailiff has not the authority [to claim for compensation] for [injuries caused on] her, before she has paid this debt.'

From a modern perspective, the instance of hina (F.SG.ACC) in (4) might give the impression of being a definite article rather than an attributive demonstrative. However, in Scandinavian, pre-nominal demonstratives (with no intervening attribute) never developed into definite articles on par with English the. The equivalent to English the debt would be skuldina, with the noun skuld 'debt' inflected for definiteness by means of the definite suffix -ina (F.SG.ACC), but the definite forms of nouns were still scarce at the time of the creation of this text. Instead, the use of demonstratives for referring to direct as well as indirect anaphora seems to have increased somewhat during a transitional period; ${ }^{7}$ only the demonstrative was then normally a form of sā/penn. Thus, even though it is article-like, we can take this instance as bearing witness to a demonstrative hinn with (weak, if any) proximal deixis.

As mentioned, there is on the whole very little evidence of hinn being used as an attributive demonstrative with proximal deixis, and none, to the best of my knowledge, from Iceland. The normal attributive demonstratives were sā/penn (distanceneutral) and sjá/pessi (with distinct proximal deixis). The first known instance of hinn 'this' is probably in the runic inscription on the whetstone from Strøm, Norway (N KJ50) from the 6th century, where the rune sequence hali hino (ACC) 'this stone' (lit.: 'stone this') is found. Considering the evidence of a demonstrative stem $h i$ - in continental Germanic (e.g. in Gothic hina, himma, hita 'this' and in the German word heute 'today' < hiu tagu 'this day'), hino could theoretically represent a Proto-Scandinavian accusative form hi-no instead of hin-no. However, as we have no other traces of a demonstrative $h i$ - in Scandinavian, it seems likely that hino is based on the hin- stem.

Other evidence of a proximal hinn, found mainly in Viking Age and mediaeval runic inscriptions, is unfortunately somewhat uncertain and indirect. ${ }^{8}$ A couple of hinn forms are found in damaged inscriptions, which means that the interpretation 'this' is not beyond doubt, even though it is very probable. There are also a number of inscriptions from the Isle of Gotland where demonstrative forms such as hinna and hitta in the sense of 'this' might bear witness to a reinforced hinn with proximal deixis. (For details, see Stroh-Wollin 2016.)

The fourth function of hinn, as a pre-adjectival article, is fairly well attested in early Mainland Scandinavian, the first instance appearing in the 9th century, as already mentioned. As also pointed out above, it seems that hinn + adjective always in its weak form - originally made up an inseparable phrase. The first instances of these phrases, found in the Viking Age runic inscriptions, normally appear post-nominally, sometimes even post-posed as in (5) from the inscription on Hs 21. 
(5)

... Gunnborga faði stæin penna, hin goða.
.. Gunnborga coloured stone this HIN good
'Gunnborga the good coloured this stone.'

The post-position in (5) indicates that hinn + adjective is not part of the inner core of the noun phrase. This kind of phrase may originally have had nominal status (see Pfaff 2019:29f.).

In Viking Age East Norse, both hinn and sā/penn were used as pre-adjectival articles; a little later, only the latter remains. Old Norwegian preserves the preadjectival hinn longer. Also, hinn + adjective turns up as a pre-nominal attribute in early Norwegian manuscripts, sometimes following sá (with a demonstrative or an article-like reading); see (6) from the miracles of Saint Olav in the Norwegian Homily Book (ed. Indrebø 1931) dated to c.1200. The combination of sá and hinn makes it sufficiently clear that hinn is not a definite article in the ordinary sense, but just an older companion to the weakly inflected adjective. The true article function should rather be associated with sá in (6). (See Stroh-Wollin 2015a for more details.)

\begin{tabular}{|c|c|c|c|c|c|}
\hline $\begin{array}{l}\text { (6) } \mathrm{pa} \\
\text { then }\end{array}$ & $\begin{array}{l}\text { syndisc } \\
\text { appeared.to }\end{array}$ & $\begin{array}{l}\text { honum } \\
\text { him }\end{array}$ & $\begin{array}{l}\text { sa } \\
S A\end{array}$ & $\begin{array}{l}\text { hinn } \\
\text { HINN }\end{array}$ & $\begin{array}{l}\text { hælgi } \\
\text { holy }\end{array}$ \\
\hline
\end{tabular}

'Then the holy king appeared to him.'

Interestingly, Storm \& Hertzberg (ibid.) remark that the pre-adjectival article 'often lacks' the $h$, in which case the vowel is 'frequently' $<\mathrm{e}>$, not $<\mathrm{i}>$. In other words, enn alternates with hinn in Old Norwegian - to some extent; how often is actually unclear (see below). According to the dictionaries of Old Danish and Old Swedish, East Norse seems to have had hinn throughout (Lund 1877, Schlyter 1877, Söderwall 1884-1918).

The fifth function of hinn identified by Storm \& Hertzberg is the suffixed definite article. It is a little surprising to find this morpheme defined as a use of hinn, as all examples given in the glossary appear as full-fledged suffixes. Nouns and endings are written as one word, the endings have no $<\mathrm{h}>$, and in cases when the noun itself ends in a vowel, even the vowel of the article is dropped; compare e.g. kirkia 'church' - kirkian (< kirikia- $n$ ) 'the church'. However, Storm \& Hertzberg presume (for very good reasons) that hinn is the origin of the suffix; only the grammaticalization seems to be completed in the Norwegian laws.

\subsubsection{Comparison Icelandic - Mainland Scandinavian}

While all the different syntactic functions accounted for above were, as far as we can judge (i.e. apart from the definite suffix), generally fulfilled by hinn in the Mainland varieties, we find a clear division of labour between hinn and enn/inn in the earliest Icelandic manuscripts.

We exclusively find hinn in function 1, i.e. as a contrastive distal demonstrative, and hinn or sá in function 2, i.e. as antecedents to relative clauses; see the examples from the Icelandic Homily Book (ed. Andrea de Leeuw van Weenen $1993=\mathrm{IH}$ ) in (7) and (8) below (from IH 80r and IH 79v, respectively). The underlining in (8) marks the relative clause following the antecedent hinn. 
(7) En annar af péim piófom es crosfester voro mep honom ... mælte. and other of PEIM thieves REL crucified were with him said Ef pu ert cristr. georpu pic héilan oc os. Pa svarape annarr. if you are Christ make yourself unhurt and us then answered other oc avitape hinn. oc mælte.... and rebuked HINN and said

'And one of the thieves who were crucified together with him said: If you are Christ, heal yourself and us. Then the other answered and rebuked the former and said ...'

(8) Enge hofom vér conung nema keisera. oc hverr sa er sic no have we king except emperor and whoever SA REL himself gerer conung. oc sva hinn es hefia vill hann. epa hallda makes king and likewise HINN $\overline{R E L}$ raise wishes him or follow ba stendr a mót keisara. then stands against emperor

'We have no king but Caesar, and whoever declares himself a king, as well as the one who wishes to raise him or follow him, (then) [he] is defying Caesar.'

There is no Icelandic evidence of either hinn or enn/inn in function 3, i.e. as a demonstrative with proximal deixis. Functions 4 and 5, on the other hand, are well attested. This is where we find the $h$-less forms; see (9) and (10) below (from IH 75v and $\mathrm{IH} 76 \mathrm{v}$, respectively). The example in (9) shows a pre-adjectival article (function 4 ) and the example in (10) two post-nominal definiteness markers (corresponding to function 5), one cliticized in hollena 'the hall' (-ena, F.SG.ACC) and one free, noncliticized, in bops ens 'the feast' (ens, N.SG.GEN).

(9) Tva sono atti enn fyrsti mapr adám,
two sons owned ENN first man Adam

two sons owned ENN first man Adam

oc var annarr peirra gópr en annar vanndr.

and was other their good and other bad

'The first man Adam had two sons, and one of them was good and the other evil.'

(10) Conungr gecck inn i hollena oc sa yfir

king went in.to hall-ENA and looked over

lip pat er comit var til bops ens.

people PAT REL come was to feast ENS

'The king went into the hall and eyed the people who had come to the feast.'

Occasionally, pre-adjectival hinn forms turn up even in very early documents, e.g. in the Icelandic Homily Book from c.1200, but it is not until the 14th century that they really gain ground. According to a master's thesis by Brenden Driscoll (Driscoll 2017), the transition 'from inn to hinn' seems to have been more or less complete around 1400. Driscoll's result seems sufficiently clear on this point. 
Table 1. The number and share of pre-adjectival + pronominal hinn and pre-adjectival enn/inn in the oldest Norwegian and Icelandic manuscripts, based on Holtsmark 1955 and Larsson 1891.

\begin{tabular}{|c|c|c|c|c|c|c|c|c|}
\hline & \multicolumn{2}{|c|}{$\begin{array}{l}\text { Norwegian } \\
\text { except NH }\end{array}$} & \multicolumn{2}{|c|}{$\mathrm{NH}$} & \multicolumn{2}{|c|}{$\mathrm{IH}$} & \multicolumn{2}{|c|}{$\begin{array}{l}\text { Icelandic } \\
\text { except IH }\end{array}$} \\
\hline & $\mathrm{N}$ & $\%$ & $\mathrm{~N}$ & $\%$ & $\mathrm{~N}$ & $\%$ & $\mathrm{~N}$ & $\%$ \\
\hline hinn & 132 & 99 & 301 & 72 & 113 & 17 & 46 & 7 \\
\hline enn/inn & 1 & 1 & 119 & 28 & 565 & 83 & 624 & 93 \\
\hline
\end{tabular}

$\mathrm{NH}=$ the Norwegian Homily Book; $\mathrm{IH}=$ the Icelandic Homily Book

However, the author's conclusions concerning the very beginning of the process are less clear (and partly based on miscalculations of hinn forms and $h$-less forms in the Icelandic and the contemporary Norwegian books of homilies). ${ }^{9}$ The question of whether the instances of pre-adjectival hinn in the Icelandic Homily Book are due to Norwegian influence, or simply represent the first signs of a domestic development, is raised (on p. 35) but not actually discussed. It is just claimed (on p. 59) that a shift toward hinn forms (also discernible in Codex Regius of Grágás from c.1260) 'had already started to some extent in the spoken language, but ... it had little to no effect on the orthography of the time'.

Thus, Driscoll (2017) does not really come to grips with the possibility of Norwegian influence on the Icelandic Homily Book. In fact, such influence is very likely, since we know that there was an exchange of relevant religious texts across the sea; a number of sermons appear in both the Icelandic and the Norwegian books of homilies. Provided that this exchange was bidirectional, we should not only expect Norwegian influence on the Icelandic Homily Book, but also Icelandic influence on the Norwegian Homily Book. A test of this hypothesis demands evidence from the two books of homilies as well as texts that most likely are unaffected by influence of the same kind.

To this end, I have consulted the glossaries by Anne Holtsmark (Holtsmark 1955) and Ludvig Larsson (Larsson 1891), accounting for the oldest Norwegian and Icelandic manuscripts, respectively. Table 1 shows the distribution of hinn and enn/inn forms in the Norwegian Homily Book $(\mathrm{NH})$ and the Icelandic Homily Book (IH), both from c.1200, as well as in the other very early texts, i.e. dated up to $c .1250$, from Norway and Iceland that are covered by Holtsmark's and Larsson's glossaries. The numbers for hinn include both the pre-adjectival article and the pronominal uses, since the glossaries do not distinguish between these functions.

As seen in Table 1, we find many instances of enn/inn in the Norwegian Homily Book, but only one instance of an $h$-less variant in the other Norwegian texts. We also find a significantly higher share of hinn forms in the Icelandic Homily Book than in the other Icelandic texts. Presumably a vast majority, if not all, of the $7 \%$ of hinn found in the Icelandic texts except for the Icelandic Homily Book are not pre-adjectival articles, but have pronominal function; an estimate based on two thirds of the homilies in the Icelandic Homily Book predicts that there should be about eight pronominal hinn for every hundred pre-adjectival articles. 
of exception as forms of enn/inn. This holds true already in the Viking Age runic inscriptions (Stroh-Wollin 2014).

Early Icelandic manuscripts, on the other hand, offer reasonably good opportunities to study how the suffix develops from an $h$-less primitive post-nominal definiteness marker (see further, Section 4).

\subsection{The spelling of the neuter forms}

As mentioned in the introduction, the neuter singular form hið for the nominative and accusative cases of the pre-adjectival article in Icelandic goes back to hit with a short / $t$, whereas the corresponding form of the contrastive demonstrative has been hitt with a long /t:/ as far back as the records go. Even though spelling was not as firmly regulated in the Middle Ages as today, this phonological difference is orthographically already fairly well represented in Old Icelandic. The Icelandic Homily Book, for instance, has 36 neuter forms of hinn as contrastive demonstratives or as antecedents to relative clauses or 'that'-clauses, of which 35 are spelled with $<\mathrm{tt}>$ or $<\mathrm{T}>$ and only one with $<\mathrm{t}>$. There are also two neuter forms of the article, both with single $<\mathrm{t}>$.

Interestingly, the /t/ of the neuter forms of enn/inn was obviously also short. Out of the 135 instances recorded by Larsson (1891) in the oldest Icelandic manuscripts, only one is written with a geminate. This certainly also points towards a relation between the later article hinn and the former enn/inn, rather than the demonstrative hinn.

Unfortunately, the mediaeval manuscripts from the mainland are less reliable witnesses than the Icelandic ones when it comes to the orthographic representation of long and short phonemes. Also, there are not so many instances of hinn, and the neuter forms, of course, are fewer still. These are most often represented by hit, irrespective of function, but the form hint, i.e. with no assimilation $n t>t(t)$, is also recorded in East Norse (see Section 2.2 above).

\subsection{Deixis and reference}

When discussing whether we are dealing with one or two origins for hinn and enn/ inn, it is also of great relevance to consider the deictic and referential nature of the possible origin/origins, not least because the common Scandinavian demonstrative hinn in the sense of 'the other' or 'the former' represents a less common kind of deixis or reference.

It is impossible to tell exactly how the contrastive meaning 'the other/the former' of hinn in the first function accounted for above was established, but it is reasonable to suggest that it comes from some distal demonstrative. It is also highly plausible that hinn as antecedent to relative clauses and 'that'-clauses has the same origin, since we never find enn or inn forms in this position. As mentioned above, the antecedent hinn is only sometimes compatible with a reading 'the other/the former'; possibly the contrastive meaning was there from the beginning and was later neutralized.

The non-contrastive attributive demonstrative hinn (function 3), on the other hand, seems to have had proximal deixis or anaphoric reference - to judge from the very few remnants we have. This makes it troublesome to ascribe to it the same 
Table 2. Distribution of enn/inn and hinn in early Mainland Scandinavian and early Icelandic.

\begin{tabular}{|c|c|c|c|c|}
\hline Function & Deixis/Reference & $\begin{array}{l}\text { Early Mainland } \\
\text { Scandinavian }\end{array}$ & $\begin{array}{l}\text { Early } \\
\text { Icelandic }\end{array}$ & Comments \\
\hline $\begin{array}{l}\text { 1. Contrastive demonstrative: } \\
\text { 'the other/former (one)' }\end{array}$ & $\begin{array}{l}\text { Distal, } \\
\text { contrastive }\end{array}$ & hinn & hinn & \\
\hline $\begin{array}{l}\text { 2. Antecedent to relative } \\
\text { clauses and 'that'-clauses }\end{array}$ & $\begin{array}{l}\text { Cataphoric, } \\
\qquad(+/- \\
\text { contrastive })\end{array}$ & hinn & hinn & Also sā/penn \\
\hline 3. Proximal demonstrative & $\begin{array}{l}\text { Proximal or } \\
\text { anaphoric }\end{array}$ & (hinn) & $\begin{array}{l}\text { [not } \\
\text { found] }\end{array}$ & $\begin{array}{c}\text { Normally: sā/penn; } \\
\text { sjá/pessi/penni }\end{array}$ \\
\hline 4. Pre-adjectival article & - & hinn & enn/inn & $\begin{array}{l}\text { East Norse: also } \\
\text { sā/penn }\end{array}$ \\
\hline 5. Post-nominal def. marker & $\begin{array}{l}\text { Anaphoric or } \\
\text { text-external }\end{array}$ & $(-h i n n)>-i n n$ & $\begin{array}{l}(-) e n n> \\
\quad \text {-inn }\end{array}$ & \\
\hline
\end{tabular}

origin as hinn 'the other/the former', as it is problematic to suggest an original demonstrative that, at the same time, could express a strong distal deixis and a clear proximal deixis.

If we instead suggest that hinn 'this' was not in fact the same word as hinn 'the other/the former', we must assign them different backgrounds. The division of labour between hinn and enn/inn in early Icelandic may be the clue we need. The $h$-less forms in early Icelandic, used for functions that most probably developed from the proximal demonstrative, can give us a hint of what this proximal demonstrative once was like on the mainland as well. If so, it was not formally identical to the distal demonstrative from the very beginning. The merger of forms on the mainland could be the result of a Proto-Scandinavian innovation.

\subsection{Hinn vs. enn/inn: A summary}

The exposition above can now be summarized as in Table 2. Forms of hinn turn up in five distinct syntactic functions in early Mainland Scandinavian: 1) as a demonstrative contrasting the referent to something earlier mentioned, 2) as antecedent to relative clauses and 'that'-clauses, 3) as a proximal demonstrative, 4) as a preadjectival article, and 5) as a post-nominal definiteness marker. It is important to note that there is also some evidence of hinn in functions 3 and 5 on the mainland, though unfortunately it is very scarce. Early Icelandic, on the other hand, has clear evidence of hinn in functions 1 and 2 and enn/inn in functions 4 and 5, while no evidence of either word is found in function 3.

When taking into account the division of labour between the forms in Icelandic as well as the deictic and referential nature of the words, it seems reasonable to divide them into two groups. Hinn in the sense of 'the other/the former' most likely originates from a distal demonstrative. We place hinn as antecedent to relative clauses in the same group, not because it necessarily has a contrastive meaning, but because it shows up as forms of hinn, and never as forms of enn/inn, in Icelandic. As early Icelandic generally has enn/inn as pre-adjectival article and 
post-nominal definiteness marker, we place them in the other group - together with the proximal demonstrative. There is no evidence of the latter in Icelandic, but it is most likely the origin of the article and the suffix (to be).

\section{Enn vs. inn}

So far, we have only been concerned with the contrast between hinn on the one hand and the $h$-less variants enn and inn on the other. Scholars have long paid attention to this contrast, but the question of why there are two $h$-less variants has attracted less interest. However, there is a great dominance of enn forms over inn forms in the earliest Icelandic manuscripts, which certainly is worthy of our attention. As noted above, Storm \& Hertzberg (1885:287) also remark that the $h$-less forms found in the Norwegian mediaeval laws are enn rather than inn.

During later decades, the lack of interest in the significance of the vowel of the $h$ less forms may partly be due to the influential work of Hreinn Benediktsson, who shows, among other things, that unstressed /i/ was often spelled $<\mathrm{e}>$ during an early period of Icelandic. The later spelling with $<\mathrm{i}>$ in the same positions was not caused by any phonetic change in unstressed syllables, but by adjustments of the quality of the vowels in short stressed syllables (Benediktsson 2002 [1962]).

I see no reason to question this description. Just a glance at some of the homilies in the Icelandic Homily Book makes it sufficiently clear that what we expect to be instances of unstressed /i/ (at this time as well as later), e.g. in endings, is very often written $<\mathrm{e}>$. However, this fact is not per se a proof of a phonetic realization of $<\mathrm{enn}>$ as inn. Moreover, the hinn forms are consistently written with $<\mathrm{i}>$, also when occasionally found in pre-adjectival position in early Icelandic, where it competes with enn.

Interestingly, there are actually some early Icelandic texts where the scribes normally use $<\mathrm{i}>$ to represent unstressed /i/, e.g. in endings. This is the case for the sermons indexed $e, n 1$ and $n 2$ in de Leeuw van Weenen's (1993) edition of the Icelandic Homily Book from c.1200. It also applies to the Christian Laws Section of the Codex Regius of the mediaeval Icelandic collection of laws, Grágás, from c.1260 (ed. by Finsen 1852). The orthography of these texts should be reliable as a witness of the true form of the pre-adjectival article and the post-nominal definiteness marker. The distribution of the various spellings is presented in Table 3. The table accounts for the numbers of pre-adjectival enn, inn and hinn, of free (i.e. non-cliticized) post-nominal enn and inn, as well as of bound (i.e. cliticized) -enn and -inn in the four texts mentioned.

Table 3 shows that the pre-adjectival word and the free post-nominal definiteness marker are normally written as enn in the homilies investigated, whereas the bound morpheme is more often -inn than -enn. In the law text, written about 60 years later, we have a bound post-nominal -inn throughout, whereas the pre-adjectival word has both forms, though inn is more common.

To conclude, we can discern a pattern in which an original post-nominal enn takes on the normal vowel of endings when reanalysed as a regular inflectional suffix $(e n n>-e n n \rightarrow-i n n)$. Somewhat later, the spelling of the pre-adjectival word shifts from enn to inn, maybe influenced by the post-nominal suffix. 
Table 3. The numbers of enn, inn and hinn in pre-adjectival position and of free and bound (-)enn and (-)inn as definiteness markers in post-nominal position in three homilies from the Icelandic Homily Book (IH) and the Christian Laws Section of Grágás, texts which normally have $<\mathrm{i}>$ for /i/ in endings.

\begin{tabular}{|c|c|c|c|c|c|c|c|}
\hline \multirow[b]{3}{*}{ Text } & & & & \multicolumn{4}{|c|}{ Post-nominal } \\
\hline & \multicolumn{3}{|c|}{ Pre-adjectival } & \multicolumn{2}{|c|}{ Free } & \multicolumn{2}{|c|}{ Bound } \\
\hline & enn & inn & hinn & enn & inn & -enn & $-i n n$ \\
\hline $\mathrm{IH}: \mathrm{e}$ & 6 & 1 & 0 & 4 & 0 & 6 & 19 \\
\hline $\mathrm{IH}: \mathrm{n} 1$ & 18 & 1 & 2 & 5 & 0 & 11 & 52 \\
\hline $\mathrm{IH}: \mathrm{n} 2$ & 12 & 2 & 0 & 14 & 1 & 8 & 73 \\
\hline Grágás: KB & 32 & 47 & 0 & 0 & 0 & 0 & 76 \\
\hline
\end{tabular}

Thus, the earliest form of the pre-adjectival article and the post-nominal definiteness marker in Icelandic was enn, not inn; i.e. the latter is secondary to the former. Furthermore, if enn - not inn - is the original form, it is less probable that the process began with hinn. The gradual development of the Icelandic pre-adjectival article was enn $\rightarrow$ inn $\rightarrow$ hinn, not the reverse.

\section{History and etymology of hinn and hinn}

As outlined in the introduction, the dispute about the history of the words discussed here, in their different guises and uses, has primarily concerned whether we should believe in a one-source or a two-source theory. A one-source theory suggests either that an $h$-less variant has arisen from hinn by $h$-drop or that hinn, in some way or another, is secondary to enn/inn. The two-source theory suggests two different origins for the contrastive demonstrative and the article. The proposal advocated here makes things a bit more nuanced, as briefly explained in Section 5.1 below. Another issue under debate is the origins of the words. This matter is treated in Section 5.2. Section 5.3 presents the conclusions.

\subsection{One source, two sources, or ...?}

From the preceding exposition, it seems sufficiently clear that the two different hinn words recognized in present-day Icelandic do not have the same origin. The demonstrative hinn remains unaltered since the earliest attestations, whereas the preadjectival article started as enn. Accordingly, I see no reason not to assume separate ancient origins for these two words.

The early varieties on the Scandinavian mainland do not, as we have seen, show the same distribution of hinn and enn/inn across different functions as early Icelandic does. On the mainland, the pre-adjectival article also generally turned up as forms of hinn (when not sä/penn) and, contrary to the development in Iceland, nothing speaks in favour of any other origin of the definite suffix than hinn, which lost its initial $h$ when cliticizing to the noun.

Now, does this mean that we shall expect there to have been some ProtoScandinavian variety with an inherited en-pronoun, later reflected in the 
Icelandic enn, and another variety covering most of the mainland, where this word was lost at an early stage or never actually was used, which would mean that one and the same hin- stem gave rise to all the diverse functions of hinn forms on the mainland? Perhaps one cannot fully rule out this possibility. However, as argued above, it is somewhat problematic to assume that one word should have developed such very disparate deictic and referential properties as the ones associated with the various uses of hinn in the early mainland varieties.

As already briefly outlined, the state of affairs in Icelandic offers an attractive alternative to this assumption, viz. if we take the early Icelandic enn as a relic of a common Proto-Scandinavian demonstrative and take the corresponding hinn in the contemporary mainland varieties (i.e. the pre-adjectival article and the source of the definite suffix) as originating from the outcome of an early reinforcement of the en- demonstrative. In addition, there was also of course a common ProtoScandinavian hin-stem, later visible in the contrastive demonstrative and in the antecedent to relative clauses and 'that'-clauses all over Scandinavia.

This proposal means that neither of the usual one-source or two-source theories can fully elucidate whether, and if so how, hinn and enn/inn are related. On the one hand, it means that we have two anciently inherited demonstrative stems, hin- and en-. On the other hand, it also means that we have an innovated hin-pronoun based on the en-stem on the mainland and, furthermore, a late development enn $\rightarrow$ inn $\rightarrow$ hinn in Iceland.

\subsection{The origins and development of enn and hinn}

It seems clear that enn and the older hinn, in some way or another, derive from two pronominal Proto-Indo-European (PIE) stems, ${ }^{\star}$ eno- and ${ }^{*} \hat{k} o$ - (in some variant, see later in this section). Pokorny (1959:319) lists both the article enn/inn 'the' and the demonstrative hinn 'that' in his account for the PIE root ${ }^{\star}$ eno-, hinn as a result of a combination of ${ }^{\star} \hat{k} o$ - and ${ }^{\star} e n o-$. However, the picture given by etymologists and other scholars concerning the more exact development of the Scandinavian words is less clear. One problem is that it is sometimes difficult to figure out whether a word is taken to be an ancient inheritance or a Scandinavian innovation. The latter is regularly assumed, I imagine, because many scholars have been eager to seek a link to non-Scandinavian Germanic languages.

For instance, if enn (inn) is distinguished as an independent word, i.e. not taken to be a shortened hinn, it is often associated with Gothic jains and German jener and other related words in other West Germanic varieties (e.g. English yon, yonder), albeit sometimes with reservation considering the uncertainty. (See e.g. SAOB (vol. 11, 1931: hin), Hellqvist 1948 (hin), de Vries 1962 (inn1), Blöndal Magnússon 1989 (hinn2), Nielsen 1989 (\$582).) Formally, this connection is unproblematic, as Scandinavian lost initial / $\mathrm{j} /$ during the Proto-Scandinavian period, and the $<\mathrm{ai}>$ in Gothic jains most probably represented a monophthong. However, the words mentioned have the kind of contrastive meaning which we associate with the common Scandinavian hinn 'the other/the former', but not with the presumed precursor of enn.

The possibility to derive enn directly from the PIE pronominal stem ${ }^{\star} e n o$ - is apparently not considered, in spite of the fact that it is formally uncomplicated and would relieve us of the contrastive meaning of jains, jener, etc. 
It is also problematic, as is sometimes suggested, to see the origin of the contrastive hinn in a Proto-Scandinavian combination of a pronominal or locative stem ${ }^{\star} h i$ - or ${ }^{\star} h \bar{i}$ - $\left(<\mathrm{PIE}{ }^{\star} \hat{k} o-\right)$ and the $e n$ - stem (or as a derivation of ${ }^{\star} h \bar{i}$ - with an $n$ suffix, as proposed in Hellqvist 1948, also referred to in Nielsen 1989). The problem is not that the combination as such is impossible. On the contrary, I suggest this is how we get the 'new' hinn 'this'. We have good evidence of ${ }^{\star} h i$ - and ${ }^{\star} h \bar{\imath}$ - in other Germanic words, but its compatibility with hinn 'the other/the former' can be questioned, as these words (e.g. Gothic hinna, himma, hitta 'this', German heute < hiu tagu 'this day', English here < hèr) express proximal deixis.

The ${ }^{\star} h i$ - and ${ }^{\star} h \bar{i}$ - stems go back to variants of Proto-Indo-European ${ }^{\star} \hat{k} o$-, the former most likely to ${ }^{\star} \hat{k} i-$, the latter to ${ }^{*} \hat{k} e i$-. Some etymologists refer, in one way or another, to one or both possibilities in their accounts of hinn, but they are vague concerning the dating of the Scandinavian word. De Vries (1962), for instance, takes hinn as having developed from a compound of Proto-IndoEuropean ${ }^{*} \hat{k} o$ - and ${ }^{*} e n o-$, but does not explicitly say it is an ancient inheritance, and his remark that the second part of the word may have developed from jains opens the way for a later dating. Blöndal Magnússon (1989) takes hinn as a derivation of some Germanic stem beginning in $h-\left({ }^{\star} h e-,{ }^{\star} h i-,{ }^{\star} h a-\right.$ or $\left.{ }^{\star} h \bar{i}-\right)$, but, nevertheless, demonstrates the development from Indo-European forms beginning in $k$-, ${ }^{*} \hat{k} o-e n o s$ or ${ }^{*} \hat{k} e i n o s$.

From the point of view of the deixis, it would in fact be more appealing to derive hinn 'the other/the former (one)' directly from an Indo-European form, as the proximal nature of the Germanic ${ }^{\star} h i$ - and ${ }^{\star} h \bar{i}$ - is troublesome for the hypothesis of a later word formation. Even though the first element would be etymologically the same if emanating from a pre-Germanic ${ }^{*} \hat{k} i$ - or ${ }^{*} \hat{k} e i$-, the longer time span leaves more room for assuming a more relevant deixis. It is also noteworthy that we actually have empirical evidence of PIE ${ }^{*} \hat{k} e i n o s$ with distal deixis in the Greek demonstrative (e)keinos 'that'.

Accordingly, the secondary hinn on the mainland may very well stem from a combination of a Germanic stem such as ${ }^{\star} h i$ - or ${ }^{\star} h \bar{i}$ - and the $e n$ - stem. This would first give us a reinforced $e n$ - demonstrative with proximal deixis and then the early pre-adjectival article and the post-nominal definite suffix. Even if we have poor evidence of the proximal demonstrative, we may be able to trace it back to the 6th century, if the rune sequence hino on the whetstone from Strøm is a true instance of hin- (see Section 3 above).

Is it possible now to more precisely characterize the first elements of both hindemonstratives, the ancient common Scandinavian one and the Proto-Scandinavian innovation? From the point of view of word formation, the attachment of a locative element to the original pronominal stem seems more attractive than a combination of two pronominal stems. This speaks in favour of the ancient hinn being a direct development from ${ }^{*} \hat{k} e i n o s\left(<\mathrm{PIE}{ }^{*} \hat{k} e i+{ }^{*}\right.$ enos $)$ and the innovated hinn being a combination of Proto-Scandinavian ${ }^{\star} h \bar{\imath}-\left(<\mathrm{PIE}^{\star} \hat{k} e i\right)$ and the $e n$ - stem. Even though both words in such a case would go back to exactly the same Proto-Indo-European roots, they may represent different deixis. Since the Greek demonstrative (e)keinos expressed distal deixis, it is definitely possible to assume the same for the anciently inherited hinn if it developed directly from ${ }^{\star} \hat{k}$ einos. One the other hand, the Germanic ${ }^{\star} h \bar{\imath}$ - stem, as well as ${ }^{\star} h i$-, expressed proximal deixis; ${ }^{\star} h \bar{i}$ - is for instance 
the first element of the Mainland Scandinavian adverb hit [hi:t] 'here/this way', a combination of *hi - 'here-' and at 'to'.

The Scandinavian evidence of ${ }^{\star} h \bar{i}$ - in the adverb hit also speaks in favour of the locative ${ }^{\star} h \bar{i}$ - rather than the pronominal ${ }^{\star} h i$ - being the first element of the innovated hinn. There is, as mentioned, clear evidence of the ${ }^{\star} h i$ - stem in various Germanic varieties, but not on Scandinavian ground. However, assuming a first element with a short rather than long vowel would be attractive from the point of view that the vowel of the hin-stem is short. The same kind of reasoning is applicable to the ancient hinn, as we could expect PIE ${ }^{\star} \hat{k} e i$ - to result in ${ }^{\star} h \bar{l}$ - with a long /i:/, whereas for instance PIE ${ }^{\star} \hat{k} i$ - would give ${ }^{\star} h i$ - with a short $/ \mathrm{i} /$. Thus, if there once was a long /i:/, we must assume a general shortening of it later on, not only in the forms with long consonants, such as the masculine, singular, nominative form hinn, which would be expected, but also in forms with short consonants, such as the feminine, singular, nominative hin; compare the corresponding forms of 'my': minn (MASC.SING.NOM) and min (FEM.SING.NOM).

For the time being, I still prefer to view ${ }^{\star} h \bar{\imath}$ - as the first element of the innovated proximal demonstrative and ${ }^{\star} \hat{k} e i$ - as the original first element of the anciently inherited, and plausibly originally distal, demonstrative, but I have no answer to why the paradigms in that case ended up with short /i/ in all forms.

Another circumstance that remains unclear is why the neuter singular forms for the nominative and accusative cases of the Icelandic article ended in a short $/ t /$, as is reflected in present-day Icelandic as $/ \delta /$. We would rather expect an assimilation of the $n$ of the stem and the ending - $t$ to result in a long /t:/, just as in the corresponding forms of the contrastive demonstrative hitt. However, the short / $t /$ must be of an old date, since even the earliest manifestations of the neuter forms of the article are et and it.

It is also interesting that the short / $\mathrm{t} /$ remained when the article shifted from inn to hinn during the 14th century. This means in all probability that the article hinn in some way is connected with enn/inn and cannot be understood just as an expanded use of the domestic demonstrative, but it is not self-evident exactly how or why the change from inn to hinn took place. We can certainly assume there was some acquaintance in Iceland with a pre-adjectival hinn, parallel to enn/inn, early on, whether domestic to some extent or caused by (later) Norwegian influence, and evidently the hinn forms eventually took over. One can speculate that this may have been caused by intensified Norwegian influence in the 14th century, or the shift may have had something to do with the development of mandatory definiteness marking. However, such speculations are beyond the scope of this paper. I confine myself to the claim that the Icelandic article hinn is in some way a descendant of enn/inn, not of the contrastive demonstrative hinn.

\subsection{Conclusions}

The discussion above can now be summarized as follows.

- The demonstrative hinn and the pre-adjectival hinn in Old Scandinavian, to some extent still found in present-day Icelandic, do not have the same background. Despite the formal merger between them, we should treat them as originally having been two separate words. 
- The former hinn appeared all over mediaeval Scandinavia in two syntactic functions: as a demonstrative with contrastive deixis and as an antecedent to relative clauses or 'that'-clauses. I take this hinn to be anciently inherited from some Indo-European pronoun combining a variant of the roots ${ }^{\star} \hat{k} o$ and ${ }^{\star} e n o-$, maybe ${ }^{\star} \hat{k} e i n o s$, with a parallel in Greek (e)keinos 'that'. Just as with the Greek pronoun, we can assume that the original Scandinavian variant of the word had distal deixis.

- Beside the distal hin- demonstrative, we can assume an anciently inherited demonstrative based on the stem en-, going back to the PIE root ${ }^{*} e n o-$.

- The en- pronoun gave rise to a strengthened variant, a Proto-Scandinavian innovation, of which hino in the runic inscription on the whetstone from Strøm ( $6^{\text {th }}$ century) is perhaps the first evidence. The first element of the strengthened demonstrative was probably ${ }^{\star} h \bar{i}$ - or ${ }^{\star} h i$-, i.e. Germanic variants of PIE ${ }^{\star} \hat{k} o-$. The ${ }^{\star} h \bar{i}$ - and ${ }^{\star} h i$ - roots expressed proximal deixis, which we can also assume concerning the innovated hin-demonstrative; compare hali hino 'this stone' in the Strøm inscription.

- We have very poor evidence, however, of hin- as a proximal demonstrative and none at all of en-as a deictic demonstrative, but both pronouns survive in the secondary functions of pre-adjectival article and post-nominal definiteness marker, later the definite suffix. These secondary functions were mainly fulfilled by enn in early Icelandic and by hinn in the early varieties on the mainland.

- The parallel use of enn and the innovated hinn is due to the partial spread of the innovation; hinn did not totally oust its precursor before the colonization of Iceland around 900.

- In early Icelandic, as the grammaticalization of the definite suffix proceeded and the post-nominal enn was adjusted and became -inn, we can see a similar adjustment of the pre-adjectival article, which changed from enn to inn. During the 14th century, the $h$-less article was successively exchanged for the variant with $h$, which was not totally unknown to the Icelanders, either because of the contacts with the mainland, chiefly Norway, or because it actually was part of some Icelanders' language. Since the neuter nominative and accusative singular forms hit have short $t$, just as the corresponding forms of enn/inn, we can conclude that the article hinn is not a descendant of the contrastive demonstrative, which has neuter forms with long $t$ : hitt.

\section{A final remark}

My argumentation above has chiefly concerned a couple of circumstances that I believe have not previously been given sufficient attention when dealing with the history and etymology of hinn and hinn. First, the division of labour between hinn and enn in early Icelandic may reveal that the different uses of hinn in the contemporary varieties on the mainland are the result of a formal merger between two different words. Secondly, I believe we should not view the $h$-less forms enn and inn only as two variants in free variation; enn is the older form of the two, which means that we should trace its origin to the PIE root ${ }^{*} e n o$ - rather than to hinn dropping the $h$. 
Finally, I would like to touch upon an additional aspect of the account proposed above that diverges somewhat from the traditional line. In the literature, it is possible to suspect a certain reluctance toward etymologies that do not link Scandinavian to other Germanic varieties, such as linking enn directly to PIE ${ }^{\star}$ eno-. Instead, one readily proposes some relation to Gothic jains and German jener, irrespective of the distal/contrastive deixis of these words. The view that Scandinavian words not found in the rest of Germania must be innovations is implicit here, but now and then it is more directly expressed. One example is found in the following quote from Axel Kock (Kock 1908) concerning the origin of the Scandinavian anaphoric pronouns han $(n)$ 'he' and hon/hun 'she' (< OSc. hann and hōn, respectively).

Most linguists today probably regard Icl. hann Old Sw. han as identical to Greek [kēnos]. This etymology could be possible from a formal point of view. However it would certainly be most surprising if this Greek [kēnos] was retained only on Nordic ground, but was lost in all other Germanic languages. (Kock 1908:186; my translation)

The Greek kenos mentioned in the quote is a variant of (e)keinos (with the same distal deixis) found on the Aeolian Islands. This means that we actually have concrete evidence of two similar demonstratives in ancient Greek varieties that naturally would serve as precursors to the anaphoric pronoun hann and the contrastive demonstrative hinn in Scandinavian. Also, a derivation of hann from ${ }^{\star} k e \overline{n o s}$ is not only formally possible, as Kock puts it, but is, in fact, uncomplicated. In contrast, the etymology proposed by Kock, which links the latter part of hann (as well as the latter part of hinn) to Goth. jains, was formally problematic already when introduced. Later it has turned out to be even more improbable, as scholars today seem rather convinced that the $<\mathrm{ai}>$ in jains represents a monophthong, a short $e$ (Lehmann 1986:210), not, as assumed by Kock, a diphthong /ai/, from which he derived a long $\bar{a}$ in Proto-Scandinavian - when pronounced 'semi-fortis'.

Kock rejects the etymology prevailing at the time as improbable on the grounds that a precursor to hann, if anciently inherited, should have left some traces in non-Scandinavian Germanic. Also, a traditional textbook on language history such as the Icelandic grammar by Wessén (1961:93) describes hann, for this same reason, as a Proto-Scandinavian innovation that replaced an older ${ }^{*}$ is, related to e.g. Gothic is and German er. (For a more extensive discussion on the etymology of han/hon, see Stroh-Wollin 2015b.)

Even among later scholars one can encounter the view that specific Scandinavian words, such as hinn and hann, must be innovations. For example, Syrett (2002:723) writes: 'Since neither pronominal root in ${ }^{\star}$ hin- nor ${ }^{\star}$ han- has any immediate parallels elsewhere in Germanic, it is possible to argue that they are both innovations that arose together in the [Ancient Nordic] period', the underlying assumption being that Proto-Germanic was a homogeneous language that only later split into varieties.

However, the formally most plausible etymologies of the contrastive Old Scandinavian demonstrative hinn and the early Icelandic enn, as well as the most plausible etymology of the anaphoric pronouns han and hon, all challenge this position. If we instead recognize the possibility that the tribes that populated different 
parts of Germania did not share their entire vocabulary, but also brought with them words of their own, even some grammatical words, we might find a truer picture of the prehistory of the Germanic languages - and possibly also contribute to the wider exploration of the general prehistory of this part of the world.

Acknowledgements. This article is an outcome of my project Through the Forest of Hypo-determination: The Scandinavian Case. I am indebted to the Swedish Research Council for financially supporting the project (Dnr: 2017-01533). I would also like to thank three anonymous reviewers for helpful comments on an earlier version of the paper.

\section{Notes}

1 The pre-adjectival definite article has a restricted use in modern Icelandic, as definiteness in most cases is marked only by the definite suffix on the noun and, in relevant cases, weak inflection on a preceding adjective, e.g. (gul-a) hús-ið 'the (yellow) house'. However, for a more detailed account of various patterns in noun phrases with adjectival attributes, see Pfaff $(2014,2015)$ concerning present-day Icelandic, and Pfaff (2019) concerning the development from the 13th century onward.

2 I will use the term SUFFIX for the bound post-nominal definite article below, even though this may not be fully correct for Icelandic, as it does not, contrary to e.g. case morphemes, trigger u-umlaut on the stem. 3 The Indo-European nominative ending $-s$ ended up as a dental $-r$ in Germanic. The small capital $R$ is the traditional way to represent an intermediate stage $(/ \mathrm{z} /)$ of the development.

4 The vowel of the Old Scandinavian hin- stem was short and is here consistently represented without a macron. However, it might go back to a long /i:/ (see Section 5.2).

5 The weak adjectival declension is due to a common Germanic innovation leading to double sets of adjectival forms, so-called strong forms (the original ones) and weak forms (the new ones). The Scandinavian languages of today show full or partial correspondence between weak and definite forms.

6 See example (6): sa hinn helgi konungr 'the holy king'; example (7): péim piófum es crosfester voro ... 'the thieves that were crucified ...'; example (8): hverr sa er sic gerer conung 'whoever declares himself a king'; and example (10): and lip pat er comit var ... 'the people who had come ...'.

7 It may be of importance that the first element of the compound skuldar-kona 'indebted woman' (written as two separate words in the example) actually is the genitive form of the noun skuld 'debt'.

8 There might be another example from the Proto-Scandinavian period, viz. in the inscription on the Norwegian Eggja stone (N KJ101) from the second half of the 7th century. However, the interpretation of this inscription has been subject to much debate over the years, and the latest contributor, Ottar Grønvik (Grønvik 1988), suggests that the sequence of runes earlier taken as hin should rather be read as min. This reading is also the default variant presented in the Scandinavian Runic Text Database.

9 In fact, these figures deviate so much from the results of my own calculations that I fail to see how they were arrived at. It is stated for instance that the Norwegian Homily Book has 92 definite articles 'all of which

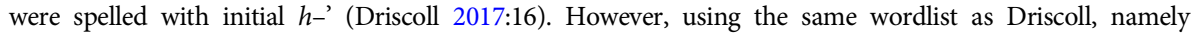
Holtsmark (1955), I get 301 instances of hinn (the vast majority of which are probably pre-adjectival articles - the wordlist does not distinguish the uses) and 119 instances of enn/inn (see Table 1).

10 Storm \& Hertzberg's (1895:287) remark that the pre-adjectival article 'often' lacks the $h$ (and in such cases is frequently written enn) may indicate some regional variation. However, the meaning of the adverb often is relative; in this case it probably means 'now and then' rather than 'very frequently'.

11 The grammaticalization ends in a definite form with double case marking. The examples show how the two instances of the masculine singular genitive ending, $-s$, originally on two separate words, the noun and the demonstrative, are retained after suffixation: hund-s-in-s (dog-GEN-DEF-GEN). Icelandic and Faroese still use double case marking on definite nouns. Mainland Scandinavian has lost case marking on nouns, but Swedish, Danish and some varieties of Norwegian use -s (irrespective of number and gender) as a possessive marker, which can be attached to any definite or indefinite form of the noun; see e.g. hundens, segmented: hund-en-s (dog-DEF-POSS), within brackets in (11). 


\section{References}

Benediktsson, Hreinn. 2002 [1962]. The unstressed and non-syllabic vowels of Old Icelandic. In Guðrún Pórhallsdóttir (ed.), Linguistic Studies, Historical and Comparative by Hreinn Benediktsson, 74-91. Reykjavík: Institute of Linguistics.

Blöndal Magnússon, Ásgeir. 1989. Íslensk Orðsifjabók [Icelandic etymological dictionary]. Reykjavík: Orðabók Háskólans.

Codex De la Gardie 4. Ms., Uppsala University Library.

de Leeuw van Weenen, Andrea (ed.). 1993. The Icelandic Homily Book. Perg. $154^{\circ}$ in the Royal Library, Stockholm. Reykjavík: Stofnun Árna Magnússonar á Íslandi.

de Vries, Jan. 1962. Altnordisches etymologisches Wörterbuch, 1st edn. Leiden: Brill.

Driscoll, Brenden. 2017. From inn to hinn: The development of the independent definite article in Old Icelandic and acqusition of word-initial $h$ - in the 13th and 14th centuries. MA thesis, Háskóli Íslands, Reykjavík.

Eithun, Bjørn, Magnus Rindal \& Tor Ulset (eds.). 1994. Den eldre Gulatingslova [Edition of the Old Law of Gulathing] (Norrøne tekster 6). Oslo: Riksarkivet.

Finsen, Vilhjálmur (ed.). 1852. Grágás: Isloendernes lovbog i fristatens tid utgivet efter det kongelige Bibliotheks Haandskrift [Edition of the Gray Goose Laws in Codex Regius]. København: Det nordiske litteratursamfund.

Grønvik, Ottar. 1988. Om Eggjainnskriften [On the Eggja inscription]. Arkiv för nordisk filologi 103, 36-47.

Hellquist, Elof. 1948. Svensk etymologisk ordbok [Swedish etymological dictionary], 3rd edn. Lund: Gleerups.

Holtsmark, Anne. 1955. Ordforrådet i de eldste norske håndskrifter til ca. 1250 [Glossary to the oldest Norwegian manuscripts until c.1250]. Oslo: I kommisjon hos Jacob Dybwad.

Indrebø, Gustav (ed.). 1931. Gamal norsk homiliebok. Cod. AM $6194^{\circ}$ [Edition of the Old Norwegian Homily Book in Cod. AM $6194^{\circ}$ ]. Oslo: Kjeldskriftfondet.

Jónsson, Finnur. 1921. Norsk-Islandske kultur-og sprogforhold i 9. og 10. årh [The Norwegian-Icelandic culture and language in the 9th and 10th centuries] (Historisk-filologiske meddelelser, 99-0517232-7; 3:2). København: Det Kgl. Danske Videnskabernes Selskab.

Kock, Axel. 1908. Etymologiska anmärkningar [Etymological remarks]. Arkiv för nordisk filologi 24, 179-198.

Larsson, Ludvig. 1891. Ordförrådet $i$ de älsta islänska handskrifterna: leksikaliskt ock gramatiskt ordnat [Glossary to the Oldest Icelandic manuscripts]. Lund: Lindstedts universitetsbokhandel.

Lehmann, Winfred P. 1986. A Gothic Etymological Dictionary. Leiden: Brill.

Lund, Georg Frederik Vilhelm. 1877. Det celdste danske skriftsprogs ordforråd: Ordbog til de gamle danske landskabslove, de sønderjyske stadsretter samt øvrige samtidige sprogmindesmoerker: fra omtr. 1200 til 1300 [Dictionary to Old Danish as manifested in manuscripts from c.1200-1300]. København: Reitzel.

Nielsen, Nils Åge. 1989. Dansk Etymologisk Ordbog. Ordenes Historie [Danish etymological dictionary], 4th edn. København: Gyldendal.

Pfaff, Alexander. 2014. Inside and outside - before and after: Weak and strong adjectives in Icelandic. In Petra Sleeman, Frek van de Velde \& Harry Perridon (eds.), Adjectives in Germanic and Romance, 217-244. Amsterdam: John Benjamins.

Pfaff, Alexander. 2015. Adjectival and Genitival Modification in Definite Noun Phrases in Icelandic - A Tale of Outsiders and Inside Jobs. Ph.D. dissertation, University of Tromsø.

Pfaff, Alexander. 2019. Reunited after 1000 years: The development of definite articles in Icelandic. Nordic Journal of Linguistics 42(2), 165-207.

Pokorny, Julius. 1959. Indo-European Etymological Dictionary. Indogermanisches Etymologisches Woerterbuch. http://dnghu.org/indoeuropean.html.

SAOB (Svenska Akademiens Ordbok) = Ordbok över svenska språket utg. av Svenska Akademien 1- (1898-) [Swedish Academy dictionary]. Lund: Gleerups.

Scandinavian Runic Text Database [Samnordisk runtextdatabas]. Department of Scandinavian Languages, Uppsala University. www.nordiska.uu.se/forskn/samnord.htm.

Schlyter, Carl Johan. 1877. Ordbok till samlingen av Sweriges gamla lagar [Dictionary to the Edition of Sweden's Old Laws]. Lund: Gleerups. 
Skrzypek, Dominika. 2009. The formation of the definite article in the Nordic languages. Lingua Posnansiensis 51(1), 65-76.

Söderwall, Knut Fredrik. 1884-1918. Ordbok öfver svenska medeltids-språket [Dictionary of Mediaeval Swedish] (Svenska fornskriftsällskapet. Serie 1. Svenska skrifter 27). Stockholm: Svenska fornskriftsällskapet.

Storm, Gustav \& Ebbe Hertzberg. 1895. Norges gamle love indtil 1387. Bd 5, Supplement, Glossarium, Anhang samt tilloeg og reettelser [Glossary to the Edition of Norway's Old Laws until 1387]. Christiania.

Stroh-Wollin, Ulla. 2014. Hinn, inn eller enn? Om uppkomsten av det nordiska bestämdhetssuffixet [Hinn, inn or enn? On the emergence of the Scandinavian definite suffix]. In Maria Bylin, Cecilia Falk \& Tomas Riad (eds.), Studier i svensk språkhistoria 12. Variation och förändring [Studies in Swedish language history 12: Variation and change] (Stockholm Studies in Scandinavian Philology. New series 60), 229-239. Stockholm: Stockholm University.

Stroh-Wollin, Ulla. 2015a. Från gammal man till den gamle mannen - definitmarkering i fornsvenska nominalfraser med adjektivattribut [From no definiteness to double definiteness: Definiteness marking in noun phrases with adjectival attributes in Old Swedish]. Arkiv för nordisk filologi 130, 101-138.

Stroh-Wollin, Ulla. 2015b. Han and hon: Anaphoric pronouns in Early Scandinavia. In Martin Hilpert, JanOla Östman, Christine Mertzlufft, Michael Riessler \& Janet Duke (eds.), New Trends in Nordic and Genral Linguistics (Lingua \& Litterae 42), 162-180. Berlin: Walter de Gruyter.

Stroh-Wollin, Ulla. 2016. The emergence of definiteness marking in Scandinavian: New answers to old questions. Arkiv för nordisk filologi 131, 129-169.

Syrett, Martin. 2002. Morphological developments from Ancient Nordic to Old Nordic. In Oskar Bandle, Kurt Braunmüller, Ernst Håkon Jahr, Allan Karker, Hans-Peter Naumann \& Ulf Teleman (eds.), The Nordic Languages: An International Handbook of the History of the North Germanic Languages, vol. 1, 719-729. Berlin \& New York: De Gruyter.

Torp, Alf. 1919. Nynorsk etymologisk ordbok [Norwegian etymological dictionary]. Kristiania: Aschehoug \& Co.

Wessén, Elias. 1992. Isländsk Grammatik [Icelandic grammar]. Edsbruk: Akad.-Tryck. [First published in 1961, Stockholm: Svenska bokförlaget.]

Wiktorsson, Per-Axel (ed.). 2011. Äldre Västgötalagen och dess bilagor i Cod. Holm B59. Del II [Edition of the Old Law of Västergötland in Cod. Holm B59]. Föreningen Västgötalitteratur.

Cite this article: Stroh-Wollin U (2020). Hinn and hinn: Early Icelandic as the clue to the history and etymology of two Old Scandinavian words. Nordic Journal of Linguistics 43, 205-228. https://doi.org/ $10.1017 /$ S0332586520000086 